\title{
Abbott \\ A case of collagenous gastroenteritis with pseudomembranes
}

\author{
Mark R Borgaonkar MD MSc FRCPC, Altaf Taher MD FRCPC
}

\begin{abstract}
$\mathrm{A}^{5}$ 51-year-old woman was admitted to hospital with a two-month history of watery diarrhea and $9 \mathrm{~kg}$ weight loss. Stool frequency was eight to 10 per day but without blood, steatorrhea or abdominal pain. There was no history of recent antibiotic use or infectious contacts. Her history was significant for type I diabetes mellitus treated with insulin. She was a lifelong nonsmoker who consumed no alcohol. The family history was unremarkable. Physical examination was normal. Laboratory data showed an elevated white blood cell count of $13.3 \times 10^{9} / \mathrm{L}$ (normal range $4.8 \times 10^{9} / \mathrm{L}$ to $10.8 \times 10^{9} / \mathrm{L}$ ), a C-reactive protein level of $15.4 \mathrm{mg} / \mathrm{L}$ (normal range $0 \mathrm{mg} / \mathrm{L}$ to $8 \mathrm{mg} / \mathrm{L}$ ) and an albumin level of $19 \mathrm{~g} / \mathrm{L}$ (normal range $33 \mathrm{~g} / \mathrm{L}$ to $45 \mathrm{~g} / \mathrm{L}$ ). Her tissue transglutaminase level was $0 \mathrm{U} / \mathrm{mL}$ (normal range $0 \mathrm{U} / \mathrm{mL}$ to $10 \mathrm{U} / \mathrm{mL}$ ) with a normal immunoglobulin $\mathrm{A}$ level. Stool testing was negative for bacterial and parasitic pathogens, while Clostridium difficile testing was negative on three separate occasions.
\end{abstract}

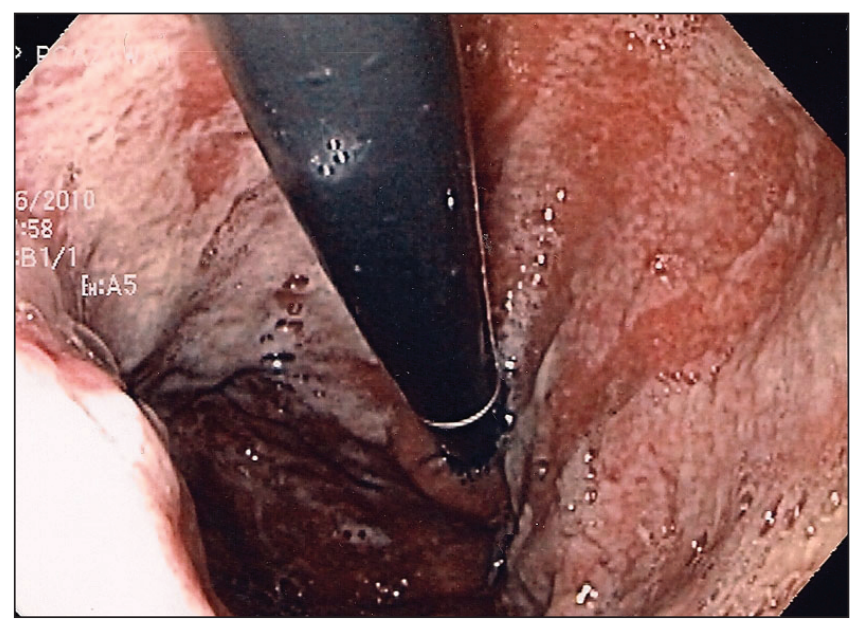

Figure 1) Gastric body with extensive pseudomembranes

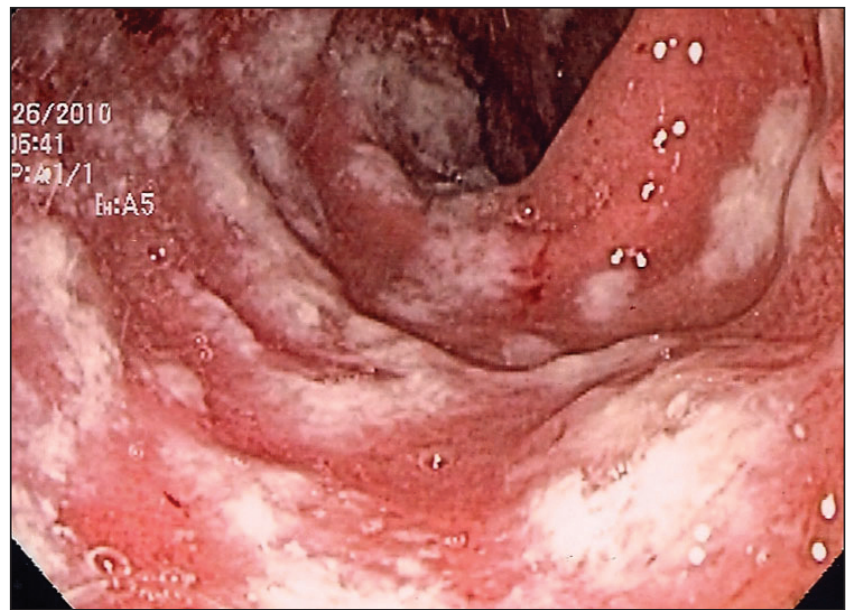

Figure 2) Duodenum with extensive pseudomembranes

\section{DIAGNOSIS}

Abdominal radiographs and computed tomography scanning both showed a fluid-filled colon but without wall thickening or features of inflammation. On esophagastroduodenoscopy, there were white pseudomembranes (PMs) in the gastric body (Figure 1), antrum and duodenum (Figure 2). Scattered PMs were also noted throughout the colon and terminal ileum. All mucosal biopsies revealed inflammation and thickened subepithelial collagen (Figure 3). A diagnosis of collagenous gastroenteritis was made and therapy was initiated with oral budesonide $9 \mathrm{mg} / \mathrm{day}$. The patient noted a prompt reduction in diarrhea, and endoscopic follow-up two and four months later showed resolution of the PMs (Figure 4) with histological improvement. The patient regained $4.5 \mathrm{~kg}$ and experienced normalization of both C-reactive protein $(1.8 \mathrm{mg} / \mathrm{L})$ and albumin $(40 \mathrm{~g} / \mathrm{L})$ levels. Budesonide

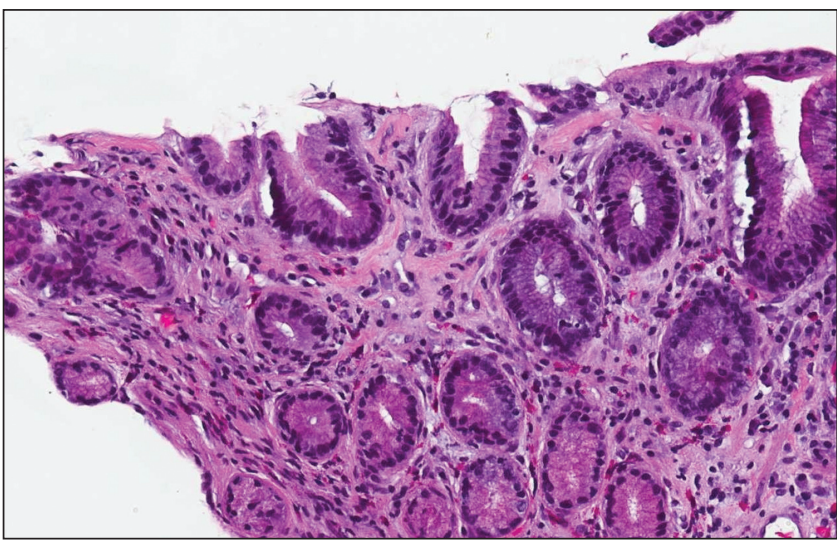

Figure 3) Gastric biopsy demonstrating thickened subepithelial collagen band and lymphocytic inflammation. Hematoxylin and eosin stain, original magnification $\times 10$

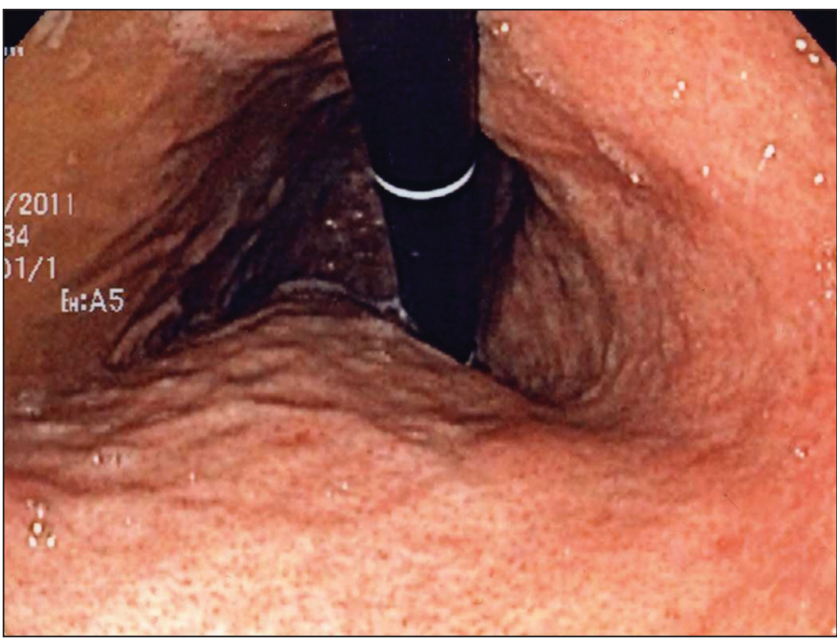

Figure 4) Gastric body post-therapy showing resolution of pseudomembranes

Memorial University of Newfoundland, St John's, Newfoundland and Labrador

Correspondence: Dr Mark R Borgaonkar, Department of Medicine, Memorial University of Newfoundland, 300 Prince Phillip Drive, St John's,

Newfoundland and Labrador A1B 3V6. Telephone 709-777-8072, fax 709-777-7054, e-mail markb@mun.ca

Received for publication February 20, 2012. Accepted March 2, 2012 
was discontinued after four months and she has remained well during the past eight months of follow-up.

\section{DISCUSSION}

Collagenous gastritis is a rare entity, with fewer than 40 reported cases (1). It may be associated with collagenous enteritis, collagenous colitis and other autoimmune diseases such as autoimmune thyroiditis and celiac disease $(1,2)$. There appears to be two different subtypes based on patient age. Children typically present with nausea, vomiting and anemia, whereas adults tend to present with diarrhea, weight loss and abdominal pain $(1,2)$. Endoscopic findings usually consist only of gastric erosions or nodularity (2). Only one other case of collagenous gastritis with endoscopic PMs has been reported (3). Optimal therapy is unclear, but case report data appears to favour steroid therapy with either budesonide or prednisone $(1,2)$.

\section{REFERENCES}

1. Gopal P, McKenna BJ. The collagenous gastroenteritides: Similarities and differences. Arch Pathol Lab Med 2010;134:1485-9.

2. Leung ST, Chandan VS, Murray JA, Wu T-T. Collagenous gastritis: Histopathologic features and association with other gastrointestinal disease. Am J Surg Pathol 2009;33:788-98.

3. Zhang HJ, Jin Z, Lin SR, et al. A case report of collagenous gastritis in a young Chinese woman and literature review. Zhonghua Nei Ke Za Zhi 2010;49:688-90.

The Canadian Journal of Gastroenterology is now considering a limited number of submissions for IMAGE OF THE MONTH. These are based on endoscopic, histological, radiological and/or patient images, which must be anonymous with no identifying features visible. The patient must consent to publication and the consent must be submitted with the manuscript. All manuscripts should be practical and relevant to clinical practice, and not simply a case report of an esoteric condition. The text should be brief, structured as CASE PRESENTATION and DISCUSSION, and not more than 700 words in length. A maximum of three to four images can be submitted and the number of references should not exceed five. The submission may be edited by our editorial team.

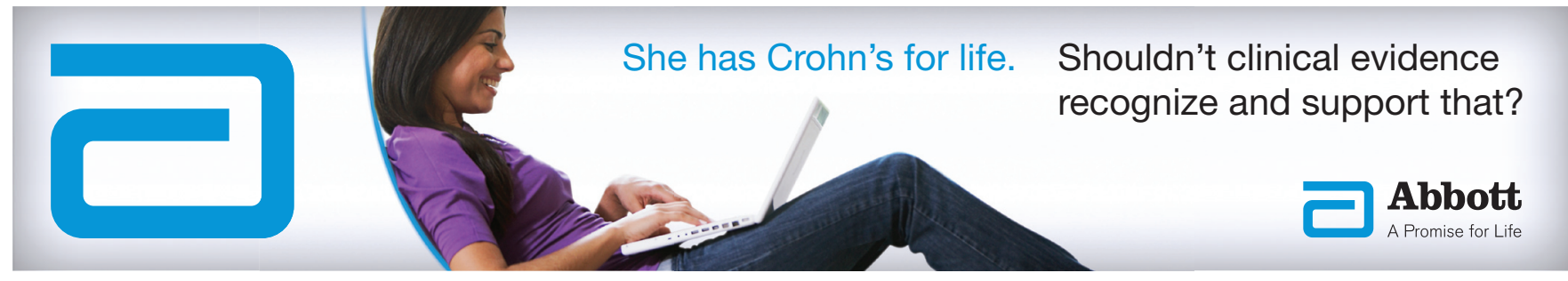




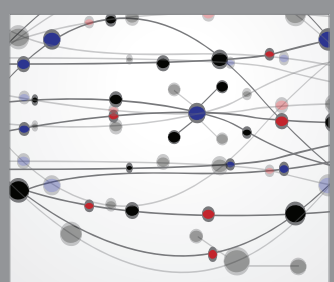

The Scientific World Journal
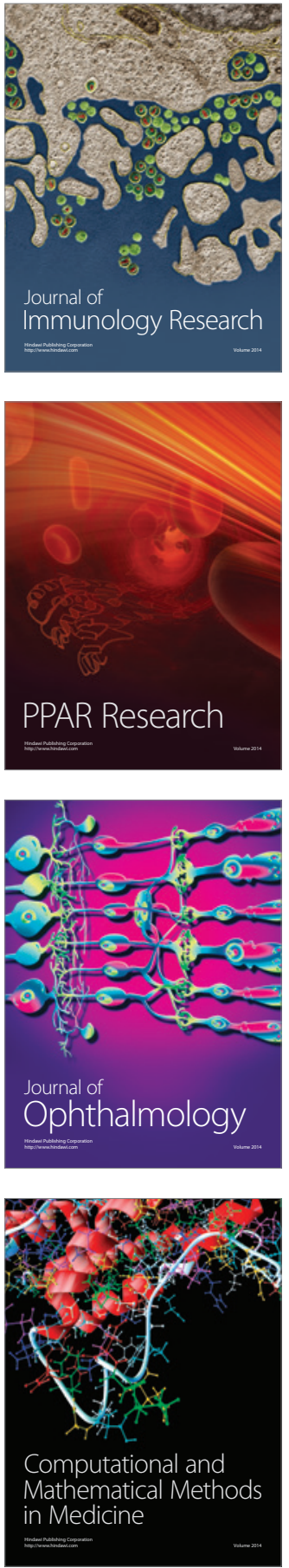

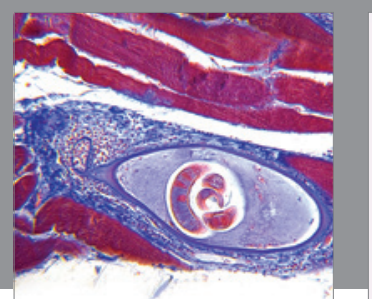

Gastroenterology Research and Practice

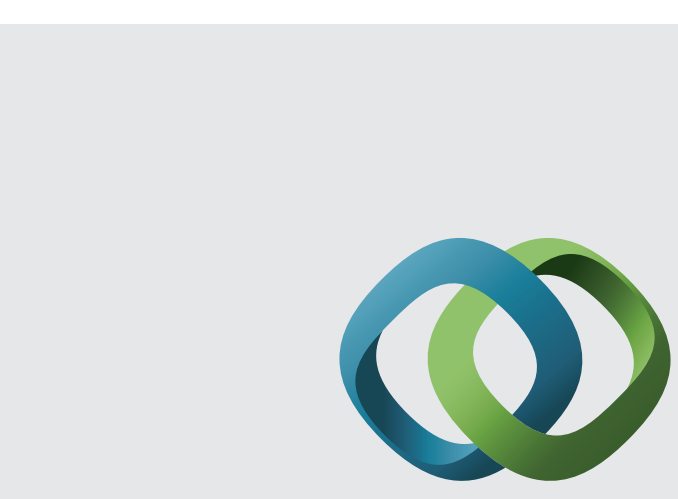

\section{Hindawi}

Submit your manuscripts at

http://www.hindawi.com
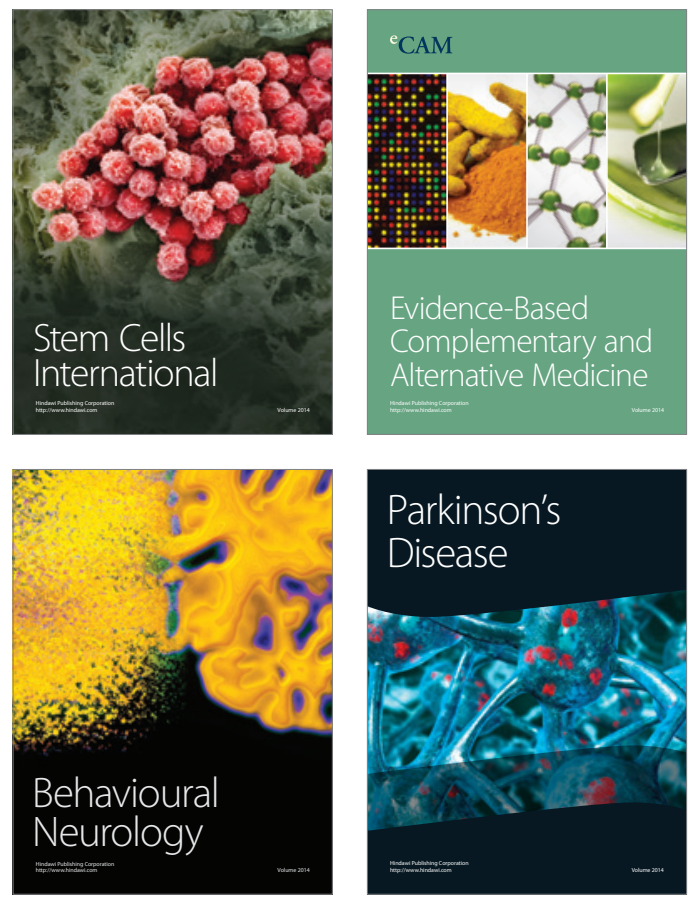
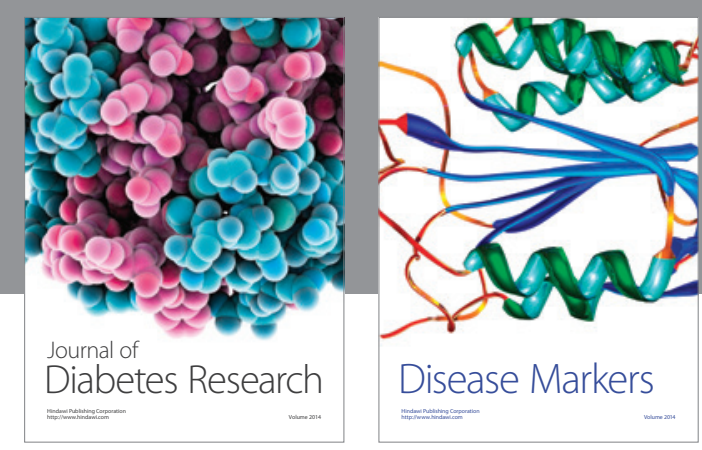

Disease Markers
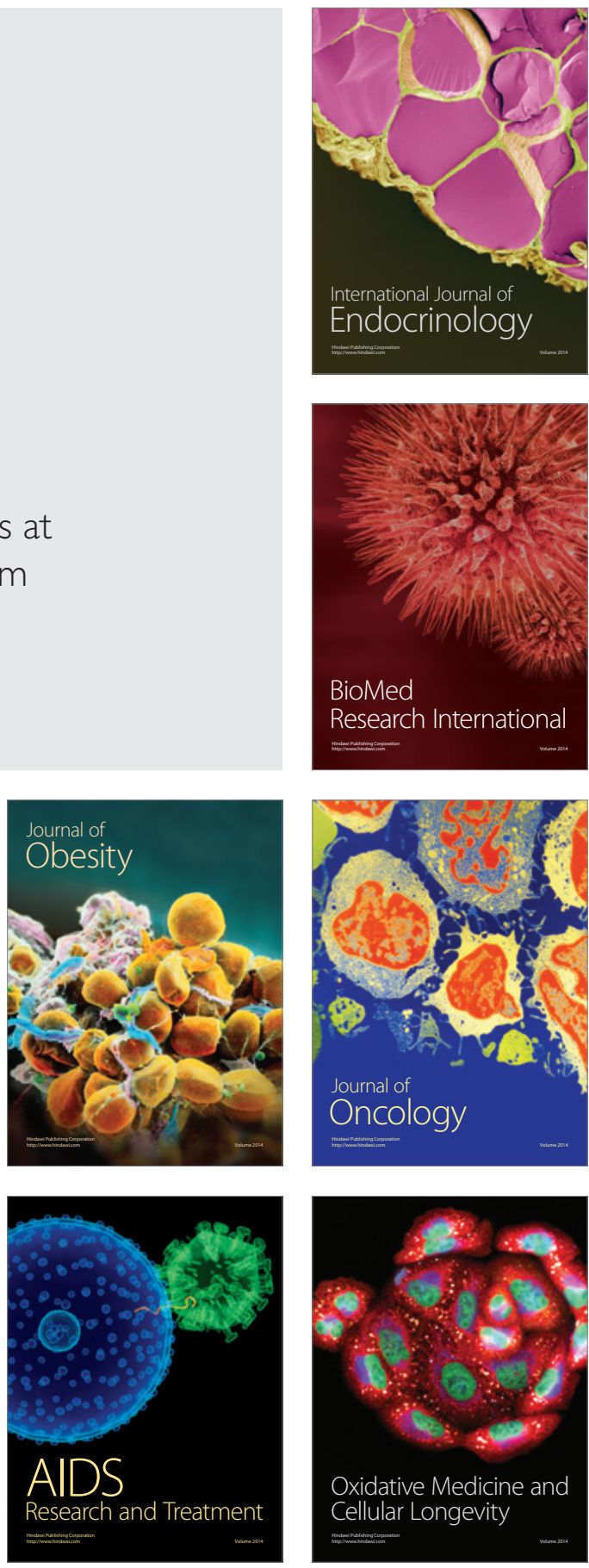